\title{
INTERLEUKIN 12 LEVELS DURING THE INITIAL PHASE OF SEPTIC SHOCK WITH PURPURA IN CHILDREN: RELATION TO SEVERITY OF DISEASE
}

\author{
Jan A. Hazelzet, ${ }^{1}$ René F. Kornelisse, ${ }^{2}$ Tineke C.T.M. van der Pouw Kraan, ${ }^{4}$ \\ Koen F.M. Joosten, ${ }^{1}$ Edwin van der Voort, ${ }^{1}$ Gerard van Mierlo, ${ }^{4}$ \\ Marja H. Suur, ${ }^{2}$ Wim C.J. Hop, ${ }^{3}$ Ronald de Groot, ${ }^{2}$ C. Erik Hack ${ }^{4}$
}

\begin{abstract}
Plasma levels of interleukin 12 (IL-12), a cytokine consisting of two different polypeptide subunits (p40 and p35), were measured together with interferon $\gamma($ IFN- $\gamma)$ and other cytokines in 46 children with septic shock and purpura. The median (range) plasma IL-12 p40 level on admission was $457(244-2677) \mathrm{pg} / \mathrm{ml}$ in non-survivors vs $189(<40-521) \mathrm{pg} / \mathrm{ml}$ in survivors $(P=<0.001)$. IL-12 p70 levels were elevated in only nine patients. IL-12 p40 plasma levels were positively correlated with tumour necrosis factor $\alpha$ (TNF- $\alpha$ ), IL-6, IL-8, IL-10 and PRISMscore, whereas they were negatively correlated with C-reactive protein (CRP), whole blood cell (WBC) and serum glucose levels. Twelve (29\%) of the patients had detectable levels of IFN- $\gamma$. Thus, circulating levels of IL-12 p40 and to a lesser extent those of IL-12 p70, are elevated in children with septic shock and purpura, and correlate with severity of disease and outcome.
\end{abstract}

C 1997 Academic Press Limited

Septic shock with purpura is a clinical syndrome predominantly caused by Neisseria meningitidis and characterized by a sudden onset and rapid progression of disease. Children younger than 10 years are most frequently affected. Lipopolysaccharide (LPS) released from Gram-negative bacteria such as meningococci initiate the production of pro-inflammatory cytokines by cells of the mononuclear-macrophage lineage and endothelial cells. Circulating levels of these cytokines, including tumor necrosis factor (TNF)- $\alpha$, interleukin (IL)-1, ${ }^{1}$ IL-6, ${ }^{1,2}$ IL- $8,{ }^{3}$ and IL-10, ${ }^{4,5}$ are increased in

From the Department of Pediatrics, ${ }^{1}$ Divisions of Pediatric Intensive Care, and ${ }^{2}$ Pediatric Infectious Diseases and Immunology, Sophia Children's Hospital/University Hospital Rotterdam, ${ }^{3}$ Department of Biostatistics and Epidemiology, Erasmus University, Rotterdam. ${ }^{4}$ Central Laboratory of the Netherlands Red Cross Blood Transfusion Services and Laboratory for Experimental and Clinical Immunology, University of Amsterdam, Amsterdam, The Netherlands.

Correspondence to: Jan A. Hazelzet, Department of Pediatrics, Division of Pediatric Intensive Care, Sophia Children's Hospital/University Hospital Rotterdam, P.O. Box 2060, 3000-CB Rotterdam, The Netherlands; E-mail: hazelzet@alkg.azr.nl

Received 17 October 1996; accepted for publication 28 February 1997

(C) 1997 Academic Press Limited

$1043-4666 / 97 / 090711+6 \$ 25.00 / 0 /$ ck970215

KEY WORDS: interleukin 12/meningococcal infections/purpura/ septic shock/T lymphocytes children with septic shock and purpura. Severity of disease is related to the initial plasma levels of LPS $^{6}$ and of these cytokines.

Interleukin 12 (IL-12), ${ }^{7,8}$ initially called natural killer cell stimulatory factor or cytotoxic lymphocyte maturation factor, is unique in that it is a heterodimeric protein composed of two different polypeptide subunits, p40 and p35 (for a review see Refs 8-14). The precise role of IL-12 in vivo is not known, although it seems to play a key role in the differentiation of Th1 cells, ${ }^{10,15}$ and in the host defense against bacterial, parasitic and viral infections. ${ }^{8}$ IL-12 also induces the production of interferon (IFN)- $\gamma$ by $\mathrm{T}$ cells and natural killer (NK)-cells. ${ }^{16,17}$ The plasma levels of IFN- $\gamma$ are increased in experimental models for sepsis $^{18-20}$ as well as in human sepsis, ${ }^{21,22}$ although not consistently. ${ }^{1}$ Recently, IL-12 was characterized as a major cytokine in the pathogenesis of gram-negative endotoxaemia in mice ${ }^{16}$ and in primates. ${ }^{23}$ We therefore questioned whether IL-12 and IFN- $\gamma$ play a role in the pathogenesis of septic shock and purpura in humans. To this purpose initial plasma levels of IL-12 and IFN- $\gamma$ were measured in children with this disease and their relation with outcome and severity of disease were studied. In addition, plasma levels of TNF- $\alpha$, IL-6, IL-8, and IL-10 were determined and the possible correlation between these cytokines and IL-12 and IFN- $\gamma$, respectively, was studied. 
TABLE 1. Clinical and laboratory parameters on admission of children with septic shock with purpura and their relation with outcome.

\begin{tabular}{lcccc}
\hline & $\begin{array}{c}\text { Total group } \\
(n=46)\end{array}$ & $\begin{array}{c}\text { Survivors* } \\
(n=17)\end{array}$ & $\begin{array}{c}\text { Non-survivors* } \\
(n=7)\end{array}$ & $P$ value** \\
\hline Age (years) & $3.8(0.5-17.9)$ & $4.9(0.5-17.9)$ & $2.2(1.4-12.3)$ & 0.259 \\
Male/female & $29 / 17$ & $9 / 8$ & $3 / 4$ & 0.653 \\
PRISM (score) & $13(1-38)$ & $9(1-20)$ & $21(17-25)$ & $<0.001$ \\
Lactate $(\mathrm{mmol} / 1)$ & $5.0(1.1-20.0)$ & $4.2(1.1-15.5)$ & $7.2(4.0-20.0)$ & 0.047 \\
WBC $\left(\times 10^{9} / \mathrm{l}\right)$ & $9.2(1.3-44.4)$ & $17.0(6.1-44.4)$ & $4.9(1.3-8.2)$ & $<0.001$ \\
Glucose $(\mathrm{mmol} / 1)$ & $5.6(1.0-14.2)$ & $8.4(1.9-14.2)$ & $2.8(1.0-10.1)$ & $\mathrm{ns}$ \\
CRP $(\mathrm{mg} / \mathrm{l})$ & $110(34-250)$ & $167(39-250)$ & $70(38-162)$ & 0.002 \\
\hline
\end{tabular}

All data shown are median (range); *data shown were obtained in patients that did not receive mAb; $P$ value for the difference between survivors and non-survivors (Mann-Whitney U-test).

\section{RESULTS}

\section{Patients}

Forty-six patients admitted to the paediatric intensive care unit (PICU) were enrolled in the study: 29 males $(63 \%)$ and 17 females $(37 \%)$. The median age was 3.4 years (range 0.5-17.9). Cultures of blood, cerebrospinal fluid or skin biopsies revealed $N$. meningitidis in 40 patients and Haemophilus influenzae in one patient. Cultures were sterile in five patients. Thirty-one $(67 \%)$ patients needed mechanical ventilation. Forty-four of the children participated in a randomized, placebo-controlled trial to study the efficacy of a human monoclonal antibody, HA-1-A (Centoxin ${ }^{\circledR}$, Centocor, Malvern, PA), in meningococcal septic shock. HA-1-A or placebo was administered after blood was collected for the determination of cytokines and other laboratory parameters. Twenty-four of these patients were treated with a placebo, 17 patients survived $(71 \%)$, seven patients died $(29 \%)$. The results of only these 24 patients were used for outcome analysis.

\section{Clinical and laboratory parameters}

Clinical and laboratory parameters obtained on admission [PRISM Paediatric Risk of Mortality-score, arterial lactate, whole blood cell (WBC), serum levels of glucose and CRP] for the total group and separately for survivors and non-survivors of the placebo group, are indicated in Table 1. As expected, all parameters were significantly associated with outcome.

\section{IL-12 p40 and p70 levels on admission}

Levels of IL-12 p40 in surviving (and also in non-surviving) patients were significantly higher than in the controls $(P<0.001)$. The median (range) plasma IL-12 p40 level on admission (Fig. 1) was 457 (244-2677) $\mathrm{pg} / \mathrm{ml}$ in non-survivors vs $189(40-521)$ $\mathrm{pg} / \mathrm{ml}$ in survivors $(P<0.001)$. In contrast, IL-12 p70 was elevated in only nine patients. The median level of
IL-12 p40 for those patients with detectable IL-12 p70 levels $(n=9)$ was significantly higher $(P=0.007)$ in comparison with those without detectable levels of IL-12 p70 ( $n=32)$ : 457 (76-2677) and 207 (40-1007), respectively. The ratio $(\mathrm{p} 40 / \mathrm{p} 70)$ in the nine patients with detectable IL-12 p70 levels was 117 (26-203) (Fig. 2).

\section{Relation between IL-12 and other cytokines on admission}

IL-12 p40 plasma levels on admission were positively correlated with tumour necrosis factor $\alpha$ (TNF- $\alpha$ ), IL-6, IL-8, and IL-10 (Table 2). The association between IL-12 p70 and the other cytokines was different in comparison with that between IL-12 p40 and the other cytokines. Patients with detectable IL-12 p70 levels had significantly higher levels of IL-8 $(P=0.042)$ and IL-12 p40 $(P=0.007)$ levels than patients with undetectable levels of IL-12 p70.

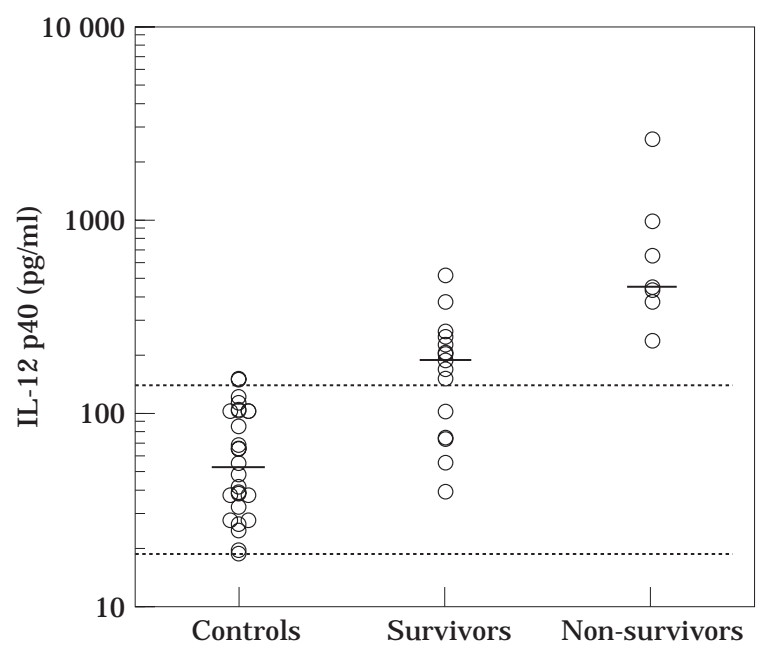

Figure 1. Plasma levels of IL-12 p40 on admission of children with septic shock with purpura (placebo treated, $n=24$ ) and of healthy controls $(n=26)$.

Solid lines represent median values. Dashed lines indicate the range of normal values. 


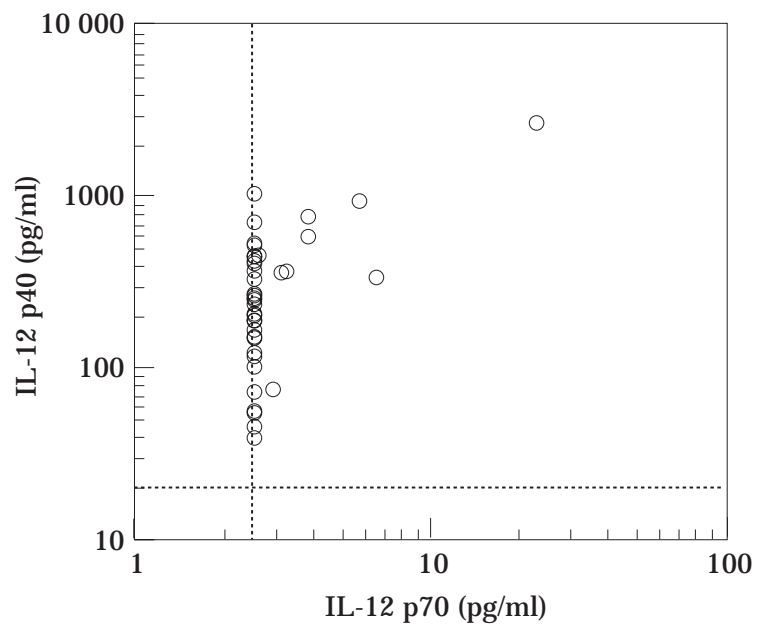

Figure 2. Scattergram of IL-12 p40 vs IL-12 p70.

Data represent the levels on admission. Dashed lines represent the lower detection limits.

\section{Relation of IL-12 to clinical and laboratory parameters}

A negative correlation was found between CRP levels or WBC vs plasma IL-12 p40 levels (Table 3). Plasma IL-12 p40 levels correlated positively with the PRISM-score and negatively with serum glucose levels. Patients with detectable levels of IL-12 p70 had significantly lower serum glucose levels $(P=0.019)$.

\section{Interferon $\gamma$}

Twelve of the $41(29 \%)$ patients had detectable levels of IFN- $\gamma$. In those 12 patients, levels of TNF- $\alpha$, IL-6, IL-8, and IL-10, but not IL-12 p40 were significantly $(P<0.005)$ increased in comparison with patients with undetectable levels of IFN- $\gamma$. In addition, those 12 patients had significantly $(P<0.005)$ lower WBC and a significantly $(P<0.05)$ higher serum lactate. From the nine patients with a detectable level of IL-12 p70, five had a detectable level of IFN- $\gamma$ $(56 \%)$, while of the 30 patients without detectable levels of IL-12 p70, only six had a detectable level of IFN- $\gamma(20 \%)$. Due to small numbers this difference did not reach statistical significance $(P=0.08)$.

TABLE 2. Correlation between IL12 p40 and TNF- $\alpha$, IL-6, IL-8, or IL-10 on admission of children with septic shock and purpura.

\begin{tabular}{lcr}
\hline & \multicolumn{2}{c}{$\begin{array}{c}\text { IL-12 } \mathrm{p} 40 \\
(n=41)\end{array}$} \\
& $r^{*}$ & \multicolumn{1}{c}{$P$ value } \\
\hline TNF- $\alpha$ & 0.45 & 0.003 \\
IL-6 & 0.56 & $<0.001$ \\
IL-8 & 0.60 & $<0.001$ \\
IL-10 & 0.51 & 0.001 \\
\hline
\end{tabular}

*Spearman's rank coefficient of correlation.
TABLE 3. Correlation between IL12 p40 and several clinical or laboratory parameters on admission of children with septic shock and purpura.

\begin{tabular}{lcc}
\hline & \multicolumn{2}{c}{ IL-12 $\mathrm{p} 40$} \\
& $r^{*}$ & $P$ value \\
\hline PRISM & 0.42 & 0.005 \\
Lactate & 0.16 & 0.286 \\
WBC & -0.56 & $<0.001$ \\
Glucose & -0.39 & 0.01 \\
CRP & -0.33 & 0.028 \\
\hline *Spearman's rank coefficient of correlation.
\end{tabular}

\section{DISCUSSION}

This is the first report showing that levels of IL-12 $\mathrm{p} 40$, and to a lesser extent those of IL-12 p70, are elevated in meningococcal sepsis. Plasma levels of IL-12 p40 were related to outcome and to severity of disease.

IL-12 or NK cell stimulatory factor is a heterodimeric cytokine, ${ }^{7}$ which appears to play an important role as a functional bridge between natural resistance and adaptive immune response. ${ }^{12}$ During endotoxaemia in mice, IL-12, in both $\mathrm{p} 40$ and p70 forms, was detected shortly after injection of LPS. Bioactive IL-12 circulated in serum before the appearance of IFN- $\gamma$. Pretreatment with anti-IL-12 antibodies blocked the production of IFN- $\gamma,{ }^{16}$ thus protecting against lethality. ${ }^{17}$ Similar findings were reported in a model of a generalized Shwartzmann reaction in mice. ${ }^{24}$ In baboons challenged with Escherichia coli ${ }^{23}$ the systemic release of IL-12 p40 and p70 was also reported. Our study confirms that circulating levels of IL-12 are also increased in human sepsis.

IL-12 p70 was detected in only nine of the patients and these levels were only slightly increased. In these nine children, IL-8, IL-12 p40 and IFN- $\gamma$ levels were significantly higher than in patients with undetectable IL-12 p70. Levels of $p 40$ were approximately 100 times higher than those of $\mathrm{p} 70$. Such an excessive production of IL-12 p40 was also found in in vitro experiments with human peripheral mononuclear ${ }^{10,25}$ and polymorphonuclear cells ${ }^{26}$ as well as in septic baboons. ${ }^{23}$ The physiological significance of this excessive production of the free $\mathrm{p} 40$ subunit in comparison with the biologically active p70 heterodimer is not clear. It has been suggested that the $\mathrm{p} 40$ subunit has a biological activity distinct from that of $\mathrm{p} 70$ heterodimer. Mattner et al. have suggested that IL-12 bioactivity is inhibited by free $\mathrm{p} 40$ molecules. ${ }^{27}$ Studies by Ling et al.$^{28}$ revealed that human $\mathrm{p} 40$, as described in mice, exists in a monomeric and dimeric form. Again as in mice, the dimeric form was at least 20 -fold more effective than 
the monomer to inhibit the activity of IL-12 or its binding to human IL-12 receptor (IL-12R). However, in contrast to the mouse homodimer, which binds to the mouse IL-12R with similar affinity as heterodimeric mouse IL-12 itself, the receptor binding and bioactivity of the human homodimer were only $10 \%$ of the receptor binding and bioactivity of the human heterodimer. Perhaps the excess production of $\mathrm{p} 40$ in relation to the $\mathrm{p} 70$ has a regulatory role. ${ }^{29}$ Nevertheless, in vitro and in vivo studies have clearly shown that the production of $\mathrm{p} 40$ is linked to that of IL-12, ${ }^{8,23}$ and hence elevated levels of p40 subunit in our patients probably reflected the production of bioactive IL-12. Consistent herewith was the observation that patients with detectable IL-12 p70 levels had higher IL-12 p40 levels than those without detectable IL-12 p70 levels. Apparently the threshold of the IL-12 p70 assay is too high.

The positive correlation between plasma levels of IL-12 p40 or p70, and other pro-inflammatory cytokines, was not surprising since this probably reflects stimulation of cells by endotoxins. However, plasma levels of IL-10, a counter-inflammatory cytokine, also correlated positively with IL-12. In vitro, IL-10 is a potent inhibitor of LPS-dependent IL-12 production. 26,30,31 Moreover, a negative correlation between IL-10 and IL-12 was found in baboons with sepsis, suggesting that IL-10 downregulates the release of IL-12 in this sepsis model. ${ }^{23}$ Thus, the positive correlation between IL-12 and IL-10 in our patients was in contrast to the findings in baboons. We propose that the synthesis of pro- and anti-inflammatory cytokines is so strongly and continuously stimulated ${ }^{5,32}$ in patients with meningococcal sepsis, that counterregulatory mechanisms are insufficient to suppress excessive production.

IL-12 can induce IFN- $\gamma$ production by $\mathrm{T}$ and NK cells in the presence of cofactors as TNF- $\alpha$ or IL-1 $\beta .^{7}$ The role of IFN- $\gamma$ during in vitro LPS-challenge, ${ }^{30}$ in vivo endotoxemia in mice, ${ }^{16-20}$ or the generalized Shwartzman reaction in mice, ${ }^{24,33,34}$ has been well established. Disseminated intravascular coagulation and shock associated with meningococcal sepsis are considered to be the clinical counterparts of the "classical" generalized Shwartzmann reaction. However, it is not known whether IFN- $\gamma$ similarly contributes to mortality in human sepsis. IFN- $\gamma$ levels and outcome were not correlated in adult patients with septic shock ${ }^{22}$ and in children with meningococcal septic shock. ${ }^{1}$ In contrast, Girardin et al. reported high levels of IFN- $\gamma$ in children with severe meningococcal septic shock. Their plasma concentrations of IFN- $\gamma$ were related to severity of the disease and correlated with serum levels of TNF- $\alpha .{ }^{21}$ In our study, only 12 patients had plasma IFN- $\gamma$ levels above the detection limit. Those children also had significantly higher levels of other cytokines. The proportion of children that had elevated IL-12 p70 levels was higher, although just not significantly, in the group with detectable IFN- $\gamma$, compared to the group with undetectable IFN- $\gamma$. A possible explanation for the absence of a relation between IFN- $\gamma$ and IL-12 p40 is that these cytokines were not released simultaneously, as was observed in animal models for sepsis. ${ }^{23}$

The clinical and laboratory parameters in this study are commonly used to assess the severity of disease in patients with meningococcal septic shock. PRISM score is a scoring system to calculate the risk of mortality in pediatric intensive care patients. ${ }^{35}$ Serum lactate is related to the degree of circulatory failure. ${ }^{2}$ WBC and CRP are negatively correlated with the fulminant evolution of meningococcal septic shock. ${ }^{36,37}$ Low serum glucose levels are reported by some authors ${ }^{38}$ although this finding is not well understood. IL-12 p40 levels in our patients, correlated with all these parameters reflecting severity of the disease, except for serum lactate. IL-12 p70 was only related to low serum glucose. IFN- $\gamma$ was negatively related to the WBC.

In conclusion, this study is the first to report a systemic release of IL-12 and its relation with outcome, severity of disease and other cytokines, in children with septic shock and purpura. We suggest that new immunomodulatory agents in sepsis should also be studied for their effects on IL-12 production.

\section{MATERIALS AND METHODS}

\section{Study protocol}

Children above 3 months and below 18 years of age with septic shock and petecchiae/purpura were enrolled in this study. Primary or secondary referrals were admitted to the paediatric intensive care unit (PICU) of the Sophia Children's Hospital between April 1991 and October 1994. Patients were eligible for inclusion when they met the following criteria: (1) presence of petecchiae/purpura for less than $12 \mathrm{~h}$; (2) presence of shock defined as sustained hypotension (systolic blood pressure $<75 \mathrm{mmHg}$ for children between 3-12 months, $<80 \mathrm{mmHg}$ for $1-5$ years, $<85 \mathrm{mmHg}$ for 6-12 years, $<100 \mathrm{mmHg}$ for children older than 12 years) requiring intensive care treatment, or evidence of poor end-organ perfusion, defined as at least two of the following: (a) unexplained metabolic acidosis $(\mathrm{pH} \leq 7.3$ or base excess $\leq-5 \mathrm{mmol} / 1$ or plasma lactate levels $>2 \mathrm{mmol} / \mathrm{l}$ ); (b) arterial hypoxia $\left(\mathrm{PaO}_{2} \leq 75 \mathrm{mmHg}\right.$, a $\mathrm{PaO}_{2} / \mathrm{FiO}_{2}$ ratio $<250$, or a transcutaneous $\mathrm{SaO}_{2} \leq 0.96$ ) in patients without overt cardiopulmonary disease; (c) acute renal failure (diuresis $<0.5 \mathrm{ml} / \mathrm{kg} / \mathrm{h}$ for at least $1 \mathrm{~h}$ despite acute volume-loading or evidence of adequate intravascular volume) without preexisting renal disease; or (d) sudden deterioration of the baseline mental status. The paediatric risk of mortality (PRISM) $\operatorname{score}^{35}$ was calculated using the most abnormal value of each variable recorded during the 
first $4 \mathrm{~h}$ after admission at the PICU. All patients received maximal supportive therapy: antibiotics, volume suppletion, inotropic support, and mechanical ventilation. Informed consent was obtained from the parents or legal representatives. The Medical Ethics Committee of the University Hospital Rotterdam approved the study protocol.

\section{Collection of blood}

On admission arterial blood was collected within $2 \mathrm{~h}$. Blood for cytokine analysis was collected in vials containing $3.8 \%$ trisodium citrate, immediately chilled on ice, and centrifuged at $2800 \times \boldsymbol{g}$ for $15 \mathrm{~min}$ and then at $45000 \times \boldsymbol{g}$ for $30 \mathrm{~min}$ at $+4^{\circ} \mathrm{C}$. Plasma was stored at $-70^{\circ} \mathrm{C}$ until tests were performed.

\section{Assays}

White blood cell count (WBC), as well as lactate, glucose and C-reactive protein (CRP) levels were determined routinely. WBC were determined using a flow cytometer (Technicon H1-system, Technicon Instruments, N.Y.). Lactate was measured by enzymatic endpoint determination. CRP by a nephelometric assay. ${ }^{39}$

Plasma levels of TNF- $\alpha$, IL-6, IL-8, IL-10, and IFN- $\gamma$ were measured with enzyme-linked immunosorbent assays (ELISA) obtained from the Department of Immune Reagents (Central Laboratory of the Bloodtransfusion service CLB, Amsterdam) and were performed according to manufacturers' instructions. Normal levels (detection limit, taking the dilution of samples into account) for these assays are: $<5(1 \mathrm{pg} / \mathrm{ml})$ for TNF- $\alpha$; $<10(1 \mathrm{pg} / \mathrm{ml})$ for IL- $6,<20$ $(4 \mathrm{pg} / \mathrm{ml})$ for IL-8; $<30(30 \mathrm{pg} / \mathrm{ml})$ for IL-10; <10 $(2 \mathrm{pg} / \mathrm{ml})$ for IFN- $\gamma$.

\section{Assays of $I L-12$}

Il-12 p40 antigen was measured with an ELISA. ${ }^{40}$ Briefly, mAbC11.79 and biotinylated mAbC8.6, both directed against the IL-12 p40 subunit, ${ }^{25}$ were used as coating and detecting antibodies, respectively. Streptavidin-polymerized horseradish peroxidase (poly-HRP; CLB, Amsterdam, The Netherlands) was used to quantify bound antigen. Recombinant human p40 was used as a standard. Taking the dilution of tested samples into account, the lower limit of detection was $20 \mathrm{pg} / \mathrm{ml}$. Normal values in 21 healthy adults were $\leq 160 \mathrm{pg} / \mathrm{ml}$. We measured the IL-12 p40 levels in five normal children age: 43 months (36-48), the median value was: $28 \mathrm{pg} / \mathrm{ml}$. As levels of IL-12 p40 were similar in children and adults (and healthy children of young age are difficult to obtain blood from), we used both groups together as control for the septic children.

IL-12 p70 antigen was measured using a newly developed ELISA. ${ }^{23}$ Briefly, mAb20C2, which has relative specificity for the IL-12 p70 heterodimer, ${ }^{25}$ and mAbC8.6 were used as a capture and detecting antibodies, respectively. The ELISA did not measure recombinant human p40 unless concentrations $>20 \mathrm{ng} / \mathrm{ml}$ were tested. In contrast, recombinant human p70, which was used as a standard, could be detected at concentrations as low as $0.25 \mathrm{pg} / \mathrm{ml}$. To avoid cross reaction with the p40 chain, plasma samples were analysed at least at a ten-fold dilution. Therefore, the actual detection limit was $2.5 \mathrm{pg} / \mathrm{ml}$. Normal values are below this detection limit.

\section{Statistical analysis}

Results are expressed as medians (range) unless otherwise specified. Differences between groups were tested with the Mann-Whitney U-test or Fisher's exact test in case of percentages. Correlation coefficients given are Spearman's. Two-tailed $P$ values $\leq 0.05$ were considered statistically significant.

\section{Acknowledgements}

The mAbs c11-79 and c8.6 were kindly provided by $\mathrm{Dr}$ G. Trinchieri; mAb20c2 was a generous gift from Dr M. Gately. Recombinant human IL-12 p40 and p70 were kind gifts from Dr S. F. Wolf.

\section{REFERENCES}

1. Waage A, Brandtzaeg $\mathrm{P}$, Halstensen A, Kierulf $\mathrm{P}$, Espevik T (1989) The complex pattern of cytokines in serum from patients with meningococcal septic shock. Association between interleukin 6, interleukin 1, and fatal outcome. J Exp Med 169:333-338.

2. Hazelzet JA, Van der Voort E, Lindemans J, Heerdt PGJT, Neijens HJ (1994) Relation between cytokines and routine laboratory data in children with septic shock and purpura. Int Care Med 20:371-374.

3. Halstensen A, Ceska M, Brandtzaeg P, Redl H, Naess A, Waage A (1993) Interleukin-8 in serum and cerebrospinal fluid from patients with meningococcal disease. J Infect Dis 167:471-475.

4. Derkx B, Marchant A, Goldman M, Bijlmer R, Deventer SV (1995) High levels of interleukin 10 during the initial phase of fulminant meningococcal septic shock. J Infect Dis 171:229-232.

5. Kornelisse RF, Hazelzet JA, Savelkoul HFJ, Hop WCJ, Suur MH, Borsboom ANJ, Risseeuw-Appel IM, van der Voort E, de Groot R (1996) The relation between plasminogen activator inhibitor-1, proinflammatory and counterinflammatory mediators in children with meningococcal septic shock. J Inf Dis 173:1148-1156.

6. Brandtzaeg P, Sandset PM, Joo GB, Ovstebo R, Abildgaard U, Kierulf P (1989) The quantitative association of plasma endotoxin, antithrombin, protein $\mathrm{C}$, extrinsic pathway inhibitor and fibrinopeptide $\mathrm{A}$ in systemic meningococcal disease. Thromb Res 55:459-470.

7. Kobayashi M, Fitz L, Ryan M, Hewisk R, Clark S, Chan S, Loudon R, Sherman F, Perussia B, Trinchieri G (1989) Identification and purification of natural killer cell stimulatory factor (NKSF), a cytokine with multiple biological effects on human lymphocytes. J Exp Med 170:827.

8. Trinchieri G (1994) Interleukin-12: a cytokine produced by antigen-presenting cells with immunoregulatory functions in the generation of T-helper cells type 1 and cytotoxic lymphocytes. Blood 84:4008-4027.

9. Trinchieri G, Kubin M, Bellone G, Cassatella MA (1993) Cytokine cross-talk between phagocytic cells and lymphocytes: relevance for differentiation/activation of phagocytic cells and regulation of adaptive immunity. J Cell Biochem 53:301-308.

10. Chehimi J, Trinchieri G (1994) Interleukin-12: a bridge between innate resistance and adaptive immunity with a role in infection and acquired immunodeficiency. $\mathbf{J}$ Clin Immunol 14:149-161.

11. Trinchieri G, Wysocka M, D'Andrea A, Rengaraju M, Aste-Amezaga M, Kubin M, Valiante NM, Chehimi J (1992) Natural killer cell stimulatory factor (NKSF) or interleukin-12 is a key regulator of immune response and inflammation. Prog Growth Factor Res 4:355-368. 
12. Trinchieri $G$ (1993) Interleukin-12 and its role in the generation of TH1 cells. Immunol Today 14:335-338.

13. Zeh H, Tahara H, Lotze M (1994) Interleukin-12, The cytokine handbook. (2nd edn). Academic Press Ltd., pp. 239-256.

14. Trinchieri G, Scott P (1994) The role of interleukin 12 in the immune response, disease and therapy. Immunol Today 15:460-463.

15. Locksley RM, Heinzel FP, Holaday BJ, Mutha SS, Reiner SL, Sadick MD (1991) Induction of Th1 and Th2 CD4+ subsets during murine Leishmania major infection. Res Immunol $142: 28-32$.

16. Heinzel FP, Rerko RM, Ling P, Hakimi J, Schoenhaut DS (1994) Interleukin 12 is produced in vivo during endotoxemia and stimulates synthesis of gamma interferon. Infect Immun 62:4244-4249.

17. Wysocka M, Kubin M, Vieira LQ, Ozmen L, Garotta G, Scott P, Trinchieri G (1995) Interleukin-12 is required for interferon-gamma production and lethality in lipopolysaccharideinduced shock in mice. Eur J Immunol 25:672-676.

18. Heinzel FP (1990) The role of IFN-gamma in the pathology of experimental endotoxemia. J Immunol 145: 2920-2924.

19. Bucklin SE, Russell SW, Morrison DC (1994) Participation of IFN-gamma in the pathogenesis of LPS lethality. Prog Clin Biol Res 388:399-406.

20. Kohler J, Heumann D, Garotta G, LeRoy D, Bailat S, Barras C, Baumgartner JD, Glauser MP (1993) IFN-gamma involvement in the severity of gram-negative infections in mice. J Immunol 151:916-921.

21. Girardin E, Grau GE, Dayer JM, Roux-Lombard P, Lambert PH (1988) Tumor necrosis factor and interleukin-1 in the serum of children with severe infectious purpura. N Engl J Med 319:397-400.

22. Calandra T, Baumgartner JD, Grau GE, Wu MM, Lambert PH, Schellekens J, Verhoef J, Glauser MP (1990) Prognostic values of tumor necrosis factor/cachectin, interleukin-1, interferonalpha, and interferon-gamma in the serum of patients with septic shock. Swiss-Dutch J5 Immunoglobulin Study Group. J Infect Dis 161:982-987.

23. Jansen P, van der Pouw Kraan T, de Jong I, van Mierlo G, Wijdenes J, Chang A, Taylor F, Hack C (1996) Release of interleukin 12 in experimental Escherichia coli septic shock in baboons: relation to plasma levels of interleukin 10 and interferon- $\gamma$ (gamma). Blood 87:5144-5151.

24. Ozmen L, Pericin M, Hakimi J, Chizzonite RA, Wysocka M, Trinchieri G, Gately M, Garotta G (1994) Interleukin 12, interferon gamma, and tumor necrosis factor alpha are the key cytokines of the generalized Shwartzman reaction. J Exp Med 180:907-915.

25. D'Andrea A, Rengaraju M, Valiante NM, Chehimi J, Kubin M, Aste M, Chan SH, Kobayashi M, Young D, Nickbarg E, Chizzonite R, Wolf S, Trinchieri G (1992) Production of natural killer cell stimulatory factor (interleukin 12) by peripheral blood mononuclear cells. J Exp Med 176:1387-1398.

26. Cassatella MA, Meda L, Gasperini S, D'Andrea A, Ma X, Trinchieri G (1995) Interleukin-12 production by human polymorphonuclear leukocytes. Eur J Immunol 25:1-5.

27. Mattner F, Fischer S, Guckes S, Jin S, Kaulen H, Schmitt E, Rude E, Germann T (1993) The interleukin-12 subunit p40 specifically inhibits effects of the interleukin-12 heterodimer. Eur J Immunol 23:2202-2208.

28. Ling P, Gately MK, Gubler U, Stern AS, Lin P, Hollfelder K, Su C, Pan YC Hakimi Y (1995) Human IL-12 p40 homodimer binds to the IL-12 receptor but does not mediate biological activity. J Immunol 154:116-127.

29. Germann T, Rude E (1995) Interleukin-12. Int Arch Allergy Immunol 108:103-112.

30. D'Andrea A, Aste-Amezaga M, Valiante N, Ma X, Kubin M, Trinchieri G (1993) Interleukin 10 inhibits human lymphocyte interferon-j production by suppressing natural killer cell stimulatory factor/IL-12 synthesis in accessory cells. J Exp Med 178:1041-1048.

31. Gazzinelli RT, Hayashi S, Wysocka M, Carrera L, Kuhn R, Muller W, Roberge F, Trinchieri G, Sher A (1994) Role of IL-12 in the initiation of cell mediated immunity by Toxoplasma gondii and its regulation by IL-10 and nitric oxide. J Eukaryot Microbiol 41:95.

32. Brandtzaeg P, Kierulf P, Gaustad P, Skulberg A, Bruun JN, Halvorsen S, Sorensen E (1989) Plasma endotoxin as a predictor of multiple organ failure and death in systemic meningococcal disease. J Infect Dis 159:195-204.

33. Billiau A, Heremans H, Vandekerckhove F, Dillen C (1987) Anti-interferon-gamma antibody protects mice against the generalized Shwartzman reaction. Eur J Immunol 17:1851-1854.

34. Billiau A (1988) Gamma-interferon: the match that lights the fire? Immunol Today 9:37-40.

35. Pollack MM, Ruttimann UE, Getson PR (1988) Pediatric risk of mortality (PRISM) score. Crit Care Med 16:1110-1116.

36. Leclerc F, Beuscart R, Guillois B, Diependaele F, Krim G, Devictor D, Bompard Y, van Albada T (1985) Prognostic factors of severe infectious purpura in children. Intensive Care Med 11:140-143.

37. Leclerc F, Chenaud M, Delepoulle F, Francois DJ, Alain M, Valerie H (1991) Prognostic value of C-reactive protein level in severe infectious purpura: a comparison with eight other scores. Crit Care Med 19:430-432.

38. Emparanza J, Aldamiz-Echevaria L, Rerez-Yarza E (1988) Prognostic score in acute meningococcemia. Crit Care Med $16: 168-169$.

39. Sternberg J (1977) A rate nephelometer for measuring specific proteins by immunoprecipitation reaction. Clin Chem 23:1456-1464.

40. van der Pouw Kraan TC, Boeije LC, Smeenk RJ, Wijdenes J, Aarden LA (1995) Prostaglandin-E2 is a potent inhibitor of human interleukin 12 production. J Exp Med 181:775-779. 